\title{
Grzegorz Zackiewicz
}

Białystok

\section{Syndykalizm \\ - ruch i doktryna przed I wojną światową}

Syndykalizm - rozumiany zarówno w kategoriach doktryny, jak i ruchu politycznego - to zjawisko, wokół którego narosło przez lata wiele mitów i nieporozumień ${ }^{1}$. Różnice zdań niejednokrotnie dotyczyły zagadnień najbardziej fundamentalnych, nie tylko genezy, ale samej istoty opisywanego fenomenu. W ramach dyskusji toczonych zarówno przez sympatyków i wrogów ruchu, jak również przez badaczy problemu, spierano się niemal o wszystko, począwszy od podstawowej terminologii, poprzez kwestię oryginalności bądź wtórności syndykalizmu, zagadnienie jego filiacji $\mathrm{z}$ anarchizmem, marksizmem, korporacjonizmem i faszyzmem, a na ocenie syndykalistycznych koncepcji roli związków zawodowych w obecnym i przyszłym społeczeństwie kończąc².

Termin ,syndykalizm” pochodzi od francuskiego słowa syndicat, oznaczającego związek zawodowy. Jakkolwiek Francja nie była krajem, w którym organizacje związkowe miały równie długie i bogate tradycje, jak choćby w Wielkiej Brytanii, nowy kierunek zrodził się u schyłku XIX wieku właśnie nad Sekwaną. Prefiguracje poglądów, które stanowić miały trwałe elementy doktryny syndykalistycznej, odnaleźć można oczywiście dużo wcześniej, przede wszystkim w pismach Pierre'a Proudhona. Badacze wskazują w pierwszej kolejności na te fragmenty prac „ojca anarchizmu”, w których autor akcentował konieczność zdystansowania się przez proletariat od istniejących struktur politycznych, zalecał separację $w$ ramach autonomicznych organizacji i skłaniał się ku konstatacji, że fundamentem przyszłego ładu staną się zrzeszenia produkcyj-

\footnotetext{
1 Tekst powstał w ramach realizacji projektu badawczego Interpretacje i próby urzeczywistnienia idei syndykalistycznych na ziemiach polskich w I połowie XX wieku, finansowanego ze środków Ministerstwa Nauki i Szkolnictwa Wyższego.

2 Godnym polecenia, syntetycznym wprowadzeniem do omawianej problematyki jest artykuł V. R. Lorwina, Syndicalism, w: International Encyclopedia of the Social Sciences, red. D. L. Sills, t. XV, New York 1968, s. 447-451. Zob. też: B. [R. J.] Holton, British Syndicalism 1900-1914. Myths and Realities, London 1976, s. 17-23; R. Hyman, Syndicalism, w: A Dictionary of Marxist Thought, red. T. Bottomore et al., wyd. II, Oxford 1991, s. 532-534.
} 
ne ${ }^{3}$. Pogląd, iż związki zawodowe mogą w przyszłości stworzyć podstawę organizacji społeczeństwa expressis verbis wyraził w 1869 roku Eugene Hins podczas kongresu Międzynarodowego Stowarzyszenia Robotników, odbywającego się w Bazylei. Belgijski socjalista podkreślał przy tym konieczność zastosowania „dualizmu” organizacyjnego, który miałby polegać na odwołaniu się do schematu branżowego i regionalnego jednocześnie ${ }^{4}$. Zapomniany dziś Jurajczyk, Adhémar Schwitzguébel kilka lat później zarysował wizję, w której podstawą ładu po zwycięskiej rewolucji miałyby się stać umowy zawierane przez zrzeszenia robotnicze zarządzające przejętymi przez siebie zakładami; sugerował przy tym ścisłą współpracę owych zrzeszeń z federacjami lokalnych producentów, organizowanymi w takich dziedzinach jak rzemiosło czy rolnictwo ${ }^{5}$. Jakkolwiek tego rodzaju głosów było we wspomnianym okresie więcej, o krystalizacji doktryny i krzepnięciu ruchu syndykalistycznego można - jak się wydaje - mówić w sposób uprawniony dopiero w odniesieniu do ostatniej dekady XIX wieku' ${ }^{6}$.

W literaturze przedmiotu podejmowano różne próby odpowiedzi na pytanie, dlaczego nowy kierunek najwcześniej i najpełniej znalazł wyraz na gruncie francuskiego ruchu zawodowego ${ }^{7}$. Poszczególni badacze wskazywali najczęściej na specyfikę III Republiki jako państwa, gdzie z jednej strony wciąż żywy był etos rewolucyjny i oddziaływanie koncepcji takich autorów, jak choćby Proudhon, z drugiej zaś, znacząca część robotników dystansowała się od skłóconego we-

${ }^{3}$ Pisma Proudhona stanowiące zbiór zadziwiająco niespójny, pełne są sprzeczności i niekonsekwencji. Wiele kwestii m.in. stosunek myśliciela do idei strajku generalnego, czy szerzej rewolucji stało się przedmiotem rozbieżnych ocen w literaturze naukowej. Zob. dla przykładu: G. Crowder, Classical Anarchism. The Political Thought of Godwin, Proudhon, Bakunin and Kropotkin, Oxford 1991, s. 74-117; D. Grinberg, Ruch anarchistyczny w Europie Zachodniej 1870-1914, Warszawa 1994, s. 92-101; J. Joll, The Anarchists, wyd. II, London 1979, s. 45-66; L. Kołakowski, Główne nurty marksizmu. Powstanie - rozwój - rozkład, Londyn 1988, s. 171-177; F. F. Ridley, Revolutionary Syndicalism in France. The Direct Action of Its Time, Cambridge 1970, s. 25-32.

4 I. Koberdowa, Pierwsza Międzynarodówka 1864-1876. Sukcesy i porażki, Warszawa 1987, s. 152-154; R. Rocker, Anarcho-Syndicalism:Theory and Practice, Edinburgh 2004 [I wyd.: London 1938], s. 45-47. Koncepcje Hinsa spotkały się z życzliwym przyjęciem ze strony delegatów z Francji, Hiszpanii i szwajcarskiej Jury. W Hiszpanii już w latach 70. XIX wieku podjęto pierwsze próby zastosowania tego rodzaju projektów w praktyce - M. Bookchin, The Spanish Anarchists. The Heroic Years 1868-1936, New York 1978, s. 132.

5 H. Katz, The Emancipation of Labor. A History of the First International, New York 1992, s. 101; P. Laskowski, Szkice z dziejów anarchizmu, Warszawa 2006, s. 251-255, 345-346.

6 W literaturze przedmiotu można znaleźć odmienne interpretacje, przyznające palmę pierwszeństwa Hiszpanom bądź Szwajcarom z Jury i przesuwające wstecz czas powstania syndykalizmu jako odrębnego kierunku - por. np.: M. Bookchin, op. cit., s. 8. Zob. też uwagi D. Grinberga, op. cit., s. 131.

7 Obszerna charakterystyka sytuacji we francuskim ruchu robotniczym na przełomie XIX i XX wieku: G. D. H. Cole, A History of Socialist Thought, vol. III, part I: The Second International 1889-1914, London 1960, s. 323-353. 
wnętrznie ruchu socjalistycznego ${ }^{8}$. Podzielając tego typu opinie, wypada przychylić się także do głosów akcentujących znaczenie innych czynników. Nie bez racji, jak się wydaje, amerykański badacz James Billington powiązał genezę syndykalizmu z faktem, iż Francja końca XIX wieku była modelowym przykładem funkcjonowania systemu liberalno-demokratycznego, a ster rządów w kraju znalazł się wówczas w rękach zamożnego mieszczaństwa. W realiach francuskich, radykalne skrzydło ruchu związkowego uzyskało szerokie możliwości działania, nieporównywalne z sytuacją w większości ówczesnych państw. Równocześnie syndykalistyczna rewolta zwracała się przeciwko tym wartościom na których ufundowana została III Republika, a krystalizujący się prąd od początku stanowił reakcję na aktualne wydarzenia polityczne i nabierał coraz wyraźniej antyliberalnego zabarwienia9.

Nowoczesny ruch związkowy we Francji zaczął się kształtować po roku 1884, gdy władze państwowe zdecydowały się na ponowną legalizację syndykatów. Jakkolwiek w ramach francuskich związków zawodowych ścierały się różne opcje ideowe, a poszczególni działacze forsowali odmienne projekty, już po kilku latach radykalizacja ruchu stawała się widoczna. W ostatniej dekadzie XIX stulecia strajki organizowane przez robotników zmieniły charakter, coraz częściej stanowiąc nową jakość w stosunku do akcji podejmowanych wcześniej ${ }^{10}$. Większość badaczy starała się wyjaśnić wspomnianą tendencję, wskazując na przenikanie do ruchu związkowego anarchistów, rozczarowanych nieskutecznością „propagandy czynu”. Równocześnie trzeba też jednak pamiętać o narastającym u progu XX wieku wśród części francuskich robotników przekonaniu, że realizowana dotąd strategia działania nie przynosi efektów, a ewentualne współdziałanie z socjalistami ewidentnie nie służy interesom proletariatu ${ }^{11}$.

\footnotetext{
8 Warto zaznaczyć, że kontrowersje wśród badaczy problemu wywoływała lansowana przez nie-
} których autorów teza, iż zarysowujące się nad Sekwaną pod koniec XIX wieku tendencje były efektem słabości francuskich związków zawodowych, co w konsekwencji sprzyjać miało ich radykalizacji. Zob. m.in.: D. Grinberg, op. cit., s. 141-143; J. Joll, op. cit., s. 179-184; F. F. Ridley, op. cit., s. 11-24; A. S. Lindeman, A History of European Socialism, wyd. III, New Heaven 1983, s. 164-165; L. Lorwin, Conféderation Générale du Travail, w: Encyclopaedia of the Social Sciences, t. IV, New York 1958, s. 179-180; M. Waldenberg, Prekursorzy Nowej Lewicy. Studia z myśli społecznej XIX i XX wieku, Kraków 1985, s. 217-230.

9 Zdaniem autora zakres swobód demokratycznych i poziom kultury politycznej we Francji był porównywalny z sytuacją we Włoszech i w pewnym stopniu również w Wielkiej Brytanii i USA - J. Billington, Fire in the Minds of Men. Origins of the Revolutionary Faith, New York 1980, s. 419-420.

10 Por. np. dane statystyczne dotyczące ruchu strajkowego we Francji przytoczone w pracy: Ch. Tilly, L. Tilly, R. Tilly, The Rebellious Century 1830-1930, wyd. II, Cambridge Mass. 1980, s. 71-74.

11 P. H. Goodstein, The Theory of the General Strike from the French Revolution to Poland, New York 1984, s. 46-47, 60-61; D. Grinberg, op. cit., s. 127-129; D. Guerin, Anarchism. From 
Radykalne, najbardziej bojowe skrzydło ruchu związkowego we Francji $\mathrm{z}$ czasem przyswoiło określenie syndicalisme revolutionaire jako najlepiej oddające zarysowującą się tendencję ${ }^{12}$. Nazwa ta była początkowo synonimem praktycznych działan podejmowanych $\mathrm{w}$ imię gruntownej przebudowy ustrojowej przez część związkowców, i nie oznaczała żadnej spójnej teorii czy doktryny. Fakt, iż radykalny odłam ruchu związkowego nad Sekwaną rósł w siłe rzutował na treść znaczeniową samego pojęcia „syndykalizm”, coraz częściej kojarzonego $\mathrm{z}$ tendencjami jednoznacznie rewolucyjnymi. Nie należy przy tym jednak zapominać, że bojowo nastawiony odłam francuskiego ruchu zawodowego - po 1902 roku utożsamiany z Generalną Konfederacją Pracy (franc.: Conféderation Générale du Travail, CGT) - nigdy nie zapewnił sobie przewagi liczebnej nawet na gruncie związkowym, nie mówiąc o całej klasie robotniczej ${ }^{13}$. Jako istotne jawi się też pytanie, na ile proponowane przez przywódców nurtu syndykalistycznego koncepcje można uznać za w pełni reprezentatywne dla ogółu członków $\mathrm{CGT}^{14}$.

Theory to Practice, transl. M. Klopper, New York - London 1970, s. 78; F. F. Ridley, op. cit., s. 45-62; B. Tuchman, Wyniosła wieża. Świat przed pierwszq wojna 1890-1914, tłum. J. Zawadzka, Warszawa 1987, s. 105-132.

12 Określenie „rewolucyjny syndykalizm” było nazwą autentyczną, używaną przez aktywistów ruchu na przełomie XIX i XX wieku. Zastępowanie wspomnianego terminu pojęciem ,anarchosyndykalizm" wydaje się nieuzasadnione, również dlatego, że jakkolwiek anarchiści wywierali istotny wpływ na rewolucyjne syndykaty, to stanowili w ich obrębie ważny, ale bynajmniej nie jedyny nurt ideowy. Zob. uwagi M. Waldenberga, op. cit., s. 119, 430; idem, [głos w dyskusji], w: O anarchizmie, anarchii i granicach wolności, Warszawa 1981, s. 17, 60-61. Por. też: B. Russell, Drogi do wolności. Socjalizm, anarchizm i syndykalizm, tłum. A. Kurlandzka, Warszawa 1935, s. $77-78,81$.

13 Francuski ruch związkowy przed I wojną światową nie objął swym zasięgiem choćby połowy pracowników zatrudnionych w przemyśle i transporcie. Według danych oficjalnych syndykaty zrzeszały w 1906 roku 836 tysięcy osób, w 1912 roku było to nieco ponad milion. Statystyki CGT wykazywały w 1906 roku 300 tysięcy członków, ale jedynie 2/3 związkowców regularnie opłacało składki. Analogiczne dane dla 1912 roku to 600 tysięcy członków, w tym około 400 tysięcy płacących składki. Komentując przytoczone cyfry F. F. Ridley (op. cit., s. 77-79) zauważał, że były one z pewnością zawyżone, a CGT przed 1914 rokiem, w najlepszym wypadku reprezentowała 10\% robotników zatrudnionych w przemyśle, natomiast biorąc pod uwagę wyłącznie związkowców skupiała nie więcej niż połowę z nich. W literaturze przedmiotu można spotkać opinię, że liczebność CGT maksymalny pułap przed I wojną osiągnęła w roku 1908 i było to 350 tysięcy członków J.-M. Mayeur, M. Reberioux, The Third Republic from Its Origins to the Great War 1871-1914, transl. J. R. Foster, Cambridge 1987, s. 305. Zob. też: L. Lorwin, Conféderation Générale..., s. 180. 14 Skrajne stanowisko w tym względzie zajął P. Stearns, Revolutionary Syndicalism and French Labor. A Cause without Rebels, New Brunswick 1971. Zdaniem uczonego, typowe dla aktywistów CGT, także w okresie największej świetności centrali było dążenie do osiągnięcia ograniczonych celów w ramach ustroju kapitalistycznego. W opinii Stearnsa rewolucyjna retoryka liderów Konfederacji tak bardzo kontrastowała z nastawieniem związkowych mas, że werbalnie podtrzymując postulat przebudowy społecznej, przywódcy CGT w praktyce szybko wycofali się z prób jego realizacji. Tego rodzaju interpretacja - jakkolwiek inspirująca do przemyśleń - wydaje się zbyt 
Liderzy środowiska w początkach XX stulecia - Victor Griffuelhes i Emile Pouget - podkreślali, że rewolucyjny syndykalizm nie stanowi produktu intelektualnej refleksji, przeciwnie: powstał spontanicznie jako wyraz potrzeb życia ${ }^{15}$. Taka interpretacja - kładąca nacisk na samoistną ewolucję ruchu związkowego i podnosząca wyłącznie aspekt praktyczny - wydaje się jednakże trudna do utrzymania. Odżegnując się od teoretycznych uzasadnień swej aktywności, francuscy rewolucyjni syndykaliści niewątpliwie bazowali na ideach, które wcześniej znalazły odzwierciedlenie w myśli anarchistycznej i socjalistycznej. Chlubiąc się niechęcią do rozważań o charakterze programowym, w istocie program działania formułowali. Źródłami inspiracji - choć w różnym wymiarze - stały się tu nie tylko koncepcje wspomnianego już Proudhona, ale także niektóre twierdzenia Karola Marksa, myśl Michaiła Bakunina, doświadczenie Komuny Paryskiej czy blankistowski ,woluntaryzm rewolucyjny" 16 .

Prawdą jest natomiast, że doktryna syndykalistyczna przełomu XIX i XX wieku wyrażała się raczej w prostych hasłach i popularnych sloganach, aniżeli ambitnych intelektualnie propozycjach. Była „wykuwana” przede wszystkim w przemówieniach, artykułach prasowych, propagandowych broszurach, nie zaś w pracach o charakterze programowym. Nie tyle wyprzedzała praktykę ruchu, ile była raczej jej następstwem, próbą teoretycznego uzasadnienia podejmowanych działań ${ }^{17}$. Równocześnie wypada się zgodzić z opinią brytyjskiego historyka, Fredericka Ridleya, który akcentuje fakt, iż doktryna syndykalistyczna nie tylko nie została w tym okresie ,skodyfikowana”, ale rozumiana jako suma idei głoszonych przez czołowych działaczy niosła w sobie pewne sprzeczności. Tym samym, konieczna dla naukowej analizy, próba zbudowania modelowego obrazu badanego zjawiska jest w tym przypadku zadaniem wyjątkowo skomplikowanym i obarczonym groźbą daleko idących uproszczeń ${ }^{18}$.

Spośród różnych propozycji periodyzacyjnych, obecnych na gruncie historiografii, najbardziej przekonujące wydaje się uznanie roku 1895 za symboliczną

jednostronna, a wnioski sformułowane przez autora należy uznać za zbyt kategoryczne. Zob. dla przykładu analizę, której punktem wyjścia stały się polemiczne uwagi w stosunku do twierdzeń Stearnsa: G. C. Friedman, Revolutionary Unions and French Labor: The Rebels behind the Cause; or, Why Did Revolutionary Syndicalism Fail?, „French Historical Studies”, 1997, nr 2, s. 155-181.

15 Klasyczne teksty liderów CGT dostępne są w internecie: V. Griffuelhes, L'Action syndicaliste, Paris 1908, zwł. rozdz. I: Le syndicalisme (http://www.pelloutier.net/dossiers/dossiers.php? id_dossier=110); E. Pouget, La Conféderation Générale du Travail, wyd. II, Paris 1910, zwł. fragm.: L'Organization (http://www.pelloutier.net/dossiers/dossiers.php?id_dossier=78).

16 B. Moss, The Origins of the French Labor Movement 1830-1914. The Socialism of Skilled Workers, Berkeley 1980, s. 137, 140-141; F. F. Ridley, op. cit., s. 33-44; M. Waldenberg, Prekursorzy Nowej Lewicy..., s. 212-217.

17 M. Waldenberg, Prekursorzy Nowej Lewicy..., s. 120-121.

18 F. F. Ridley, op. cit., s. 1-8, 170, 262-264. 
datę wyłonienia się rewolucyjnego syndykalizmu jako odrębnego ruchu społecznego i samodzielnego nurtu myśli politycznej ${ }^{19}$. Nie tyle nawet ze względu na fakt, iż to właśnie wówczas, na kongresie w Limoges powołana została do życia Generalna Konfederacja Pracy. CGT dopiero po kilku latach stała się bowiem najważniejszym ośrodkiem zorientowanym na urzeczywistnienie idei syndykalistycznych, w połowie ostatniej dekady XIX wieku nie mając jeszcze sprecyzowanego oblicza ideowego. Przywołując datę 1895, należy raczej zaakcentować fakt ukazania się artykułu, w którym Fernand Pelloutier sformułował na łamach „Les Temps Nouveaux” główne założenia nowego kierunku ${ }^{20}$. Autor programowego tekstu zatytułowanego L'Anarchisme et les syndicats ouvriers w tym samym roku objął funkcję sekretarza Federacji Izb Pracy (franc.: Federation des Bourses $d u$ Travail, FBT). Izby pomyślane jako swoiste biura pośrednictwa pracy, czy szerzej, instytucje łagodzące napięcia społeczne, u schyłku XIX stulecia ewoluowały stając się żywotnymi ośrodkami ruchu robotniczego. Ambicje Pelloutiera sięgały znacznie dalej, ten przedwcześnie zmarły działacz pragnął zbudować na bazie Izb Pracy zalążki przyszłego społeczeństwa producentów. Równocześnie, z dystansem odnosił się do CGT, obawiając się, że w ramach słabej i zachowawczej, jak sądził, Konfederacji niemożliwe będzie przeprowadzenie wspomnianych projektów. W 1902 roku, już po śmierci Pelloutiera Federacja Izb Pracy została formalnie włączona do struktury organizacyjnej CGT, a zjednoczona organizacja zaczęła odgrywać istotną rolę w życiu politycznym Francji. Radykalnie nastawieni przywódcy ruchu, wbrew wszelkim tego rodzaju obawom nie zamierzali

19 G. D. H. Cole skłaniał się raczej ku dacie 1892, wskazując na fakt ukonstytuowania się wówczas Federacji Giełd Pracy, w których Fernand Pelloutier zaczął odgrywać wiodącą rolę - op. cit., s. 335-336. Z kolei F. F. Ridley poddając analizie francuski rewolucyjny syndykalizm, punktem wyjścia swych rozważań uczynił rok 1902, gdy powstała zjednoczona Conféderation Générale du Travail. Brytyjski historyk wyraził przy tym pogląd, że zaproponowana cezura ma raczej umowny charakter, jako że charakterystyczne dla krystalizującego się kierunku tendencje zaczęły być widoczne już wcześniej - op. cit., s. 4. Zob. też: B. Moss, op. cit., s. 144.

20 F. Pelloutier, L'Anarchisme et les syndicats ouvriers, „Les Temps Nouveaux”, nr z 2-8 XI 1895 (http://www.pelloutier.net/dossiers/dossiers.php?id_dossier=20). W swoim krótkim tekście Pelloutier w sugestywny sposób przekonywał, że syndykaty stanowią naturalną formę organizacyjną ruchu robotniczego, a równocześnie oczywistą alternatywę dla wrastających w struktury państwa burżuazyjnego partii socjalistycznych. Wierząc w zdolność proletariatu do samoorganizacji, przy ograniczeniu do absolutnego minimum czynnika instytucjonalnego w praktyce funkcjonowania związków zawodowych, autor utożsamiał je z ośrodkami krystalizacyjnymi nowej rzeczywistości społecznej. Kreśląc wizję rewolucji, Pelloutier nawiązywał do znanej formuły z czasów I Międzynarodówki, głoszącej, iż wyzwolenie klasy robotniczej musi być jej dziełem, a wiara w reformy dokonywane pod auspicjami burżuazyjnego państwa to ułuda. Skutecznie przeprowadzony strajk generalny zapoczątkować miał zdaniem działacza okres przejściowy, w którym po zburzeniu instytucji państwowych ład społeczny zostanie oparty na sieci syndykatów. Koniec historii jawił się Pelloutierowi w kategoriach urzeczywistnienia ideału ,le communisme anarchiste pur", do którego jednakże ludzkość będzie w stanie dojść dopiero po pewnym czasie. 
łagodzić napięć społecznych, ani tym bardziej przyjmować umiarkowanej strategii wzorowanej na angielskich trade-unionach ${ }^{21}$.

Francuski rewolucyjny syndykalizm przełomu XIX i XX stulecia, w czytelny sposób nawiązywał do idei walki klasowej. Jakkolwiek stosowana frazeologia nosiła marksistowskie piętno, liderzy CGT proponowali uproszczoną wizję antagonizmów społecznych, rezygnując z filozoficznej podbudowy i wszelkich teoretycznych uzasadnień. Walka klasowa - stwierdzano w licznych publikacjach to fakt oczywisty, dostrzegany przez robotników na co dzień, nie wymagający jakichkolwiek dowodów wykraczających poza zwykłe doświadczenie życiowe. Syndykaliści sceptyczni byli również wobec koncepcji głoszącej, że narastanie konfliktów klasowych, rewolucja, a w końcu likwidacja kapitalizmu, to zjawiska nieuniknione na mocy logiki dziejów. Wierząc w ostateczne zwycięstwo proletariatu, nadzieje pokładano nie w wyrokach historii, lecz we własnych wysiłkach. Charakter konfliktu miał przesądzać, że tylko całkowite zburzenie dotychczasowego porządku będzie można uznać za trwałe osiągnięcie ${ }^{22}$.

Syndykaliści z CGT nie pozostawiali wątpliwości, że szanse na zwycięstwo $\mathrm{w}$ walce klasowej wiążą $\mathrm{z}$ określonym sposobem samoorganizacji proletariatu. Wychodząc z założenia, że dla podtrzymania ducha oporu niezbędna jest całkowita izolacja klasy robotniczej od wpływów burżuazyjnych, postulowali tworzenie swoistych enklaw pozostających poza zasięgiem oddziaływania sił starego porządku. W oczywisty sposób roli tej nie mogły ich zdaniem spełnić lewicowe partie polityczne, zbudowane na zasadzie sztucznych i krótkotrwałych porozumień, nastawione na kompromisy, uzgadniające w parlamencie swoje stanowisko z wrogami klasowymi. Syndykaliści dowodzili, że ugrupowania socjalistyczne, wbrew zapewnieniom swych liderów wrastają w struktury kapitalistyczne, stając się kolejnymi agendami burżuazyjnego państwa. Tego rodzaju argumentacja uległa wzmocnieniu po tym, jak w 1899 roku, Alexandre Millerand objął tekę ministra handlu i przemysłu w rządzie, którego członkiem był kat Komuny Paryskiej, generał Gaston de Galliffet ${ }^{23}$. Wskazywano także na - rzekomo nieuchronne

21 J. Billington, op. cit., s. 424; G. D. H. Cole, op. cit., s. 335-340, 346-348; P. Laskowski, op. cit., s. 332-340. Warto przy okazji zwrócić uwagę na specyficzny model organizacyjny CGT, gdzie poszczególnym syndykatom przysługiwał podczas kongresów Konfederacji jeden głos, niezależnie od ich liczebności. Wspomniana zasada, jakkolwiek rodząca daleko idące konsekwencje i poddawana krytyce na kolejnych kongresach, nie uległa zmianie, a CGT pozostała „związkiem związków”. Na ten temat zob.: F. F. Ridley, op. cit., s. 72-77; M. Waldenberg, Prekursorzy Nowej Lewicy..., s. 218-219.

22 F. F. Ridley, op. cit., s. 170-171; M. Waldenberg, Prekursorzy Nowej Lewicy..., s. 176-177.

23 Komentując to bezprecedensowe wydarzenie, Pelloutier był przekonany, że wejście Milleranda do rządu przyczyni się do osłabienia pozycji socjalistów w środowiskach robotniczych i nie bez złośliwej satysfakcji sugerował, że „gdyby partia socjalistyczna nie istniała, należałoby ją wymyślić” - P. Laskowski, op. cit., s. 336. 
- zjawisko dochodzenia do głosu w partiach socjalistycznych, zawodowych polityków, traktujących proletariat czysto instrumentalnie. Sens tego ostatniego zarzutu był głębszy: „zawodowi politycy” rekrutować się mieli niemal wyłącznie spośród warstw wykształconych. Obok wielu innych wątków, w myśli syndykalistycznej bardzo silnie zaznaczyło się więc nastawienie antyinteligenckie. Liderzy ruchu podkreślali, że syndykalizm jest nade wszystko filozofią działania, która przyznaje prymat intuicji i odwołuje się do realiów życia, nie zaś do konceptów filozoficznych. Tym samym, prosty robotnik, ,wyedukowany” w toku walki klasowej, przekształcający świat w imię nowej moralności pracy miał być uosobieniem herosa, który nie uznaje przywództwa jakichkolwiek zewnętrznych w stosunku do proletariatu - autorytetów ${ }^{24}$.

Odrzucając partyjny model działania ruchu robotniczego, liderzy CGT opowiadali się więc za koncepcją czysto proletariackich związków zawodowych, jako autonomicznych organizacji klasy pracującej25. Syndykaty, zbudowane na gruncie wspólnego interesu ekonomicznego, rzeczywistej więzi i realnej solidarności uciskanych, miały być przy tym ogniwem łączącym teraźniejszość i przyszłość. Pełniąc póki co, przede wszystkim rolę bojowej formacji rozbijającej struktury kapitalistycznego państwa, w dalszej perspektywie stałyby się już podstawowymi komórkami nowego porządku²6.

Ideę walki klasowej prowadzonej na gruncie ekonomicznym, francuscy syndykaliści przełomu XIX i XX wieku uważali za całkowite przeciwieństwo demokracji parlamentarnej. Kryła się za tym sugestia, iż burżuazja chwyta się różnych sposobów, by osłabić bojowe nastroje i determinację klasy robotniczej, odwrócić uwagę proletariatu od spraw naprawdę fundamentalnych i skierować energię społeczną w obszary, gdzie nie będzie to groźne dla interesów warstw uprzywilejowanych. Postrzegając model liberalno-demokratyczny w kategoriach systemu „zaprojektowanego" przez burżuazję, po to, by utrzymać dotychczasowy porządek, syndykaliści sugerowali, że ustępstwa rządzących, w tym także rozbudowa ustawodawstwa socjalnego, obliczone są na tłumienie przejawów walki

24 F. F. Ridley, op. cit., s. 53-62, 171-173, 267; M. Waldenberg, Prekursorzy Nowej Lewicy..., s. 174-188, 205-209.

25 Słynna Karta z Amiens uchwalona na Kongresie CGT w październiku 1906 roku zaczynała się od stwierdzenia, że Konfederacja pozostaje niezależna od „wszelkich politycznych szkół” i skupia wszystkich robotników świadomych konieczności podjęcia walki na płaszczyźnie ekonomicznej, której celem jest zniesienie systemu pracy najemnej i władzy pracodawców - [Charte d'Amiens], w: J. Maitron, Historie du mouvement anarchiste en France (1880-1914), wyd. II, Paris 1955, s. 300-301. Polskie tłumaczenie Karty z Amiens zob. w: Anarchosyndykalizm. Strajki, powstania, rewolucje 1892-1990. Wybór tekstów, red. R. Górski, Poznań - Kraków 2006, s. 30. Por. też: F. F. Ridley, op. cit., s. 95-98.

${ }^{26}$ Dobrą ilustrację mogą tu stanowić przywoływane już fragmenty tekstu E. Pouget, $L a$ Conféderation Générale du Travail (http://www.pelloutier.net/dossiers/dossiers.php?id_dossier=78). Zob. też: F. F. Ridley, op. cit., s. 173-174; M. Waldenberg, Prekursorzy Nowej Lewicy..., s. 188-190. 
klasowej. Groźbie sprowadzenia wysiłków klasy robotniczej na manowce zapobiec mogła - jak wskazywano - jedynie odpowiednia taktyka proletariatu skupionego w związkach zawodowych. Wyrażała się ona w sztandarowym haśle ruchu: action directe. Syndykalistyczna koncepcja akcji bezpośredniej zakładała konfrontację pomiędzy kapitałem i pracą, występującymi z otwartą przyłbicą i działającymi w imię własnych interesów klasowych. Action directe niweczyć miała wszelkie próby wykreowania obrazu społecznej harmonii, rozpalać ducha buntu i w ostatecznym rozrachunku doprowadzić do emancypacji proletariatu. Nie ulega wątpliwości, że sposób, w jaki liderzy ruchu postrzegali rzeczywistość nacechowany był woluntaryzmem. Rewolucyjny syndykalizm miał też wyraźnie elitarne piętno: $\mathrm{z}$ enuncjacji czołowych działaczy przebijało przekonanie, że świadoma mniejszość zdolna jest porwać masy do działania wbrew wszelkim przeciwnościom ${ }^{27}$.

Działacze CGT uznawali potrzebę stosowania różnych form akcji bezpośredniej, takich chociażby jak sabotaż, bojkot czy label. Jednakże najczystszą ekspresją walki klasowej mógł być jedynie strajk i jako taki w pierwszych latach XX wieku dominował w strategii ruchu. Kolejne „bezpośrednie starcia” z pracodawcami, pogłębiające podziały klasowe, stymulujące konflikt, wzmacniające solidarność i rewolucyjne nastawienie robotników przybliżać miały moment, w którym proletariat gotowy już będzie mentalnie i organizacyjnie do zadania kapitałowi ostatecznego ciosu. Strajk generalny, stanowiący najwyższą formę action directe był zatem w ujęciu syndykalistów synonimem rewolucji. Liderzy CGT sugerowali przy tym, że tylko na gruncie wielkiego przemysłu robotnicy mają szanse skutecznie przeciwstawić się rządzącym. Syndykalistyczna rewolucja miała być rewolucją ekonomiczną, której ze względu na spontaniczny charakter nie sposób zaplanować, ale która już rozpoczęta nie będzie możliwa do zatrzymania ${ }^{28}$.

Sama idea strajku generalnego nie była oryginalnym projektem syndykalistów. Badacze problemu słusznie wskazywali na obecność tego typu propozycji nie tylko w dyskusjach toczonych na forum I Międzynarodówki, ale już w latach 30. XIX wieku w myśli angielskiego ruchu czartystowskiego ${ }^{29}$. Jednak

27 V. Griffuelhes, op. cit. (http://www.pelloutier.net/dossiers/dossiers.php?id_dossier=110). Por. też: F. F. Ridley, op. cit., s. 172-174, 208-219, 265; M. Waldenberg, Prekursorzy Nowej Lewicy..., s. 190-196.

28 Jako ilustracja posłużyć mogą rozdz. II (La grève générale) cytowanej pracy V. Griffuelhesa (http://www.pelloutier.net/dossiers/dossiers.php?id_dossier=111), a także fragment (La tactique l'action directe) przywoływanej już broszury E. Pouget (http://www.pelloutier.net/dossiers/dossiers. php?id_dossier=79). Por. też: F. F. Ridley, op. cit., s. 174-175; M. Waldenberg, Prekursorzy Nowej Lewicy..., s. 195-200.

${ }^{29}$ Genealogia idei strajku generalnego sięga niewątpliwie czasów jeszcze wcześniejszych. Prefiguracji tego typu koncepcji należy szukać co najmniej w XVIII wieku - J. Billington, op. cit., s. 421-422; P. H. Goodstein, op. cit., s. 11-49. 
dopiero w kręgach CGT strajk generalny urósł do rangi symbolu. Warto przy tym zauważyć, że zwłaszcza na początku XX stulecia wielu syndykalistów zdawało się wierzyć w szybkie i łatwe zwycięstwo odniesione bez rozlewu krwi. Rozpad struktur władzy miał nastąpić w wyniku odmowy pracy ze strony robotników; w takiej sytuacji rządzący politycy i fabrykanci staliby się bezsilni, nie mogąc przecież wysłać wojska do wszystkich zakładów produkcyjnych, ani też obsadzić najważniejszych choćby linii komunikacyjnych w kraju. Z czasem przytoczony sposób argumentacji tracił walory prawdopodobieństwa, a pod wpływem kolejnych doświadczeń koncepcja strajku generalnego podlegała w myśli syndykalistycznej znamiennej ewolucji. Często cytowana broszura autorstwa Emile'a Pougeta i Emile'a Patauda z 1909 roku przynosiła już obraz przypominający wojnę domową, której kulminacyjnym punktem stanie się marsz zrewoltowanych mas robotniczych na parlament ${ }^{30}$.

Skutecznie przeprowadzony strajk generalny czołowi przedstawiciele CGT przełomu XIX i XX wieku postrzegali jako śmiertelny cios zadany nie tylko systemowi kapitalistycznemu, ale także samej instytucji burżuazyjnego państwa. Wpływ myśli anarchistycznej zaznaczał się w tym względzie bardzo wyraźnie, jakkolwiek nie wszyscy prominentni działacze syndykalistyczni byli w kwestii całkowitego demontażu struktur państwowych równie konsekwentni. Warto zauważyć, że zagadnienie porewolucyjnego porządku nie stało się przedmiotem szczegółowych dyskusji na żadnym z kongresów CGT, jakie odbyły się przed I wojną. Być może, jak sugeruje Marek Waldenberg, syndykaliści mieli świadomość, że rewolucja jest w gruncie rzeczy kwestią odległej przyszłości ${ }^{31}$. Niechęć do precyzowania wizji przyszłego ładu społecznego wynikała też z pewnością z przekonania o spontanicznym charakterze przemian i łączyła się z programową niechęcią liderów ruchu do teoretyzowania. Francuski rewolucyjny syndykalizm był nade wszystko manifestacją woli działania i jako taki odwoływał się do realiów życia, nie zaś rozważań filozoficznych. Wspólne dla środowiska CGT, w najbardziej bojowym okresie funkcjonowania centrali, było jak się wydaje, przeświadczenie, że sama likwidacja źródeł zła wystarczy do tego, by nowy ład społeczny wyłonił się w sposób samorzutny. Łączyło się to także ze wspomnianym wyżej poglądem, że podstawowe komórki ustroju przyszłości, syndykaty, w momencie rozpoczęcia strajku generalnego będą już w pełni gotowe do wypełniania funkcji rusztowania, na którym opierać się będzie nowy porządek ${ }^{32}$.

Autentyczne, jak się wydaje przekonanie aktywistów CGT, że Francja znajduje się u progu rewolucji, stopniowo ulegało erozji. Doświadczenia kolejnych

30 J. Billington, op. cit., s. 425; P. H. Goodstein, op. cit., s. 61-62, 66-67; D. Grinberg, op. cit., s. 137-140; R. J. Holton, Syndicalist Theories of the State, „Sociological Review”, 1980, nr 1, s. 9-11; F. F. Ridley, op. cit., s. 140-153.

31 M. Waldenberg, Prekursorzy Nowej Lewicy..., s. 204.

32 F. F. Ridley, op. cit., s. 175; M. Waldenberg, Prekursorzy Nowej Lewicy..., s. 200-204. 
akcji strajkowych oddziaływały trzeźwiąco na tych wszystkich, którzy sądzili, że następny nieunikniony kryzys systemu kapitalistycznego musi się okazać ostatnim już etapem zmagań ze „starym światem”. Zjednoczona CGT odnosiła po 1902 roku niewątpliwe sukcesy, ale miały one zawsze wymiar „cząstkowy” i jako coraz trudniejsze jawiło się podtrzymywanie mitu strajku generalnego. Znakiem czasu były sformułowania zawarte w osławionej Karcie $z$ Amiens. Liderzy ruchu nie wyrzekli się bynajmniej wiary w „ostateczną broń” proletariatu, równocześnie jednak zaznaczali, że w „,codziennym działaniu” CGT nastawiona będzie na osiąganie ograniczonych celów, takich jak skrócenie czasu pracy, czy podwyżki płac ${ }^{33}$. Rewolucyjna retoryka w oczywisty sposób traciła swój urok, nastrój romantycznego uniesienia rozwiewał się w realiach codziennego życia, jakkolwiek dyskusyjna wydaje się teza Ridleya, że już około 1906 roku idea strajku generalnego utraciła istotne znaczenie ${ }^{34}$.

Początek końca okresu świetności CGT wyznaczyły wydarzenia rozgrywające się latem 1908 roku. Reagując na krwawą rozprawę ze strajkującymi w Draveil robotnikami, Konfederacja zapowiedziała 24-godzinny strajk generalny. Rząd Georgesa Clemenceau nie tylko udaremnił wspomniane plany, ale już wcześniej polecił aresztować przywódców centrali. CGT poniosła spektakularną klęskę, nie potrafiąc przeprowadzić action directe w sytuacji, gdy władze państwowe wypowiedziały syndykalistom otwartą wojnę, wtrącając do więzienia liderów związku ${ }^{35}$. Winnym kompromitacji uznano Griffuelhesa, który utracił stanowisko sekretarza organizacji ${ }^{36}$. Nowy lider CGT, Louis Niel musiał zrezygnować już po kilku miesiącach, powodem była kolejna druzgocąca klęska w konfrontacji z rządem. Jesienią 1910 roku fiaskiem zakończyła się następna próba zorganizowania strajku generalnego po tym, jak rząd Aristide Brianda złamał strajk kolejarzy w północnej Francji. Pikanterii całej sytuacji dodawał fakt, iż premier przed kilkunastu zaledwie laty należał do gorących admiratorów idei action directe i przekonywał wówczas, że władze muszą się okazać bezsilne w obliczu nacisku mas proletariackich ${ }^{37}$.

33 [Charte d'Amiens], w: J. Maitron, op. cit., s. 300-301.

34 F. F. Ridley, op. cit., s. 155.

35 G. D. H. Cole, op. cit., s. 360; P. H. Goodstein, op. cit., s. 76-77.

36 P. H. Goodstein (op. cit., s. 77) zwrócił uwagę na artykuł napisany przez Griffuelhesa na kilka miesięcy przed omawianymi wydarzeniami. Ówczesny sekretarz CGT konstatował fakt narastającego kryzysu organizacji, sugerując nawet, że francuski ruch robotniczy znalazł się w położeniu analogicznym do tego, które stało się udziałem proletariatu po upadku Komuny Paryskiej. Griffuelhes wyciągał stąd wniosek, że wizja zwycięskiego strajku generalnego odsunęła się w czasie, a jej urzeczywistnienie wymagać będzie długiego okresu ,przygotowań strajkowych”. Wspomniany tekst V. Griffuelhesa, Romantisme révolutionnaire [1908] w internecie: (http://www.pelloutier.net/dossiers/dossiers.php?id_dossier=57).

37 G. D. H. Cole, op. cit., s. 360-361; P. H. Goodstein, op. cit., s. 77-78. 
Wydarzenia z lat 1908-1910 nie mogły pozostać bez konsekwencji dla procesów zachodzących w CGT. Nowe kierownictwo centrali, w którym czołowe role zaczęli odgrywać Leon Jouhaux i Alphonse Merrheim, powoli przesuwało francuski ruch syndykalistyczny na pozycje reformistyczne ${ }^{38}$. Procesowi „biurokratyzacji" CGT towarzyszyło ograniczanie wpływu, jaki na strategię organizacji wywierali anarchiści ${ }^{39}$. Nie oznaczało to wszakże całkowitej rezygnacji z odwoływania się do taktyki strajkowej. W ostatnich latach przed wybuchem I wojny liderzy Konfederacji szczególne nadzieje wiązali z narastającą psychozą, wynikającą z rosnącego przekonania, że w Europie, a może i na świecie, dojdzie wkrótce do konfliktu zbrojnego na dużą skalę. Zajmująca tradycyjnie antywojenne stanowisko, ostentacyjnie niechętna uczuciom patriotycznym grupa przywódcza CGT ${ }^{40}$ zdecydowanie jednak przeceniała siłę nastrojów pacyfistycznych i prymat czynnika klasowego nad narodowym. Proklamowany na 10 XII 1912 roku - jako forma sprzeciwu wobec wojny bałkańskiej i przygotowań wojennych mocarstw strajk generalny zakończył się całkowitą klęską. Pracę porzuciło w tym dniu zaledwie około 50 tysięcy robotników, liderzy CGT - co znamienne - podawali cyfrę dwunastokrotnie wyższą, o której musieli wiedzieć, że nie ma odzwierciedlenia

38 G. D. H. Cole, op. cit., s. 361; V. R. Lorwin, The French Labour Movement, Cambridge 1979, s. 45; M. Waldenberg, Prekursorzy Nowej Lewicy..., s. 230-231.

39 Zaangażowanie anarchistów w działalność związkową, w zasadzie od początku istnienia CGT wywoływało kontrowersje w obozie wyznawców ideologii libertarnej. Zasadnicze wątpliwości budziła już sama forma organizacyjna syndykatów, zdaniem wielu, z natury rzeczy „autorytarna”. Anarchistom o nastawieniu indywidualistycznym, w oczywisty sposób nie mogła odpowiadać myśl przeciwstawienia opresyjnemu państwu nie jednostki, ale grupy zbudowanej na zasadzie solidarności ekonomicznej. Argumentów krytycznych było więcej, wśród nich przewijał się także i ten, że praktyczna działalność syndykatów, nieuchronnie prowadzi do walki o cele doraźne, cząstkowe a więc w istocie umacnia istniejący porządek społeczny. Przyjęcie przez CGT Karty z Amiens pogłębiło rozdźwięki wśród anarchistów na tle ich stosunku do związków zawodowych. Wyrażona we wspomnianym dokumencie teza, że syndykaty funkcjonują ,niezależnie od wszelkich politycznych szkół”, ze zrozumiałych względów nie mogła pozostać bez wpływu na stanowisko przedstawicieli różnych nurtów w obrębie anarchizmu. Areną, na której doszło do spektakularnej wymiany zdań na ten temat, stał się międzynarodowy kongres anarchistyczny w Amsterdamie, odbywający się w sierpniu 1907 roku. Najdalej idącym głosem w obronie rewolucyjnego syndykalizmu była wypowiedź Pierre’a Monatte’a. Francuski działacz zaapelował do słuchaczy o udzielenie „bojowym związkom zawodowym" pełnego poparcia, dowodząc, że syndicalisme revolutionaire to w istocie „anarchizm ery przemysłowej”. W odpowiedzi nestor ruchu anarchistycznego, Errico Malatesta stwierdził, iż ,,anarchizm jest czymś większym od syndykalizmu”, a zatem zaangażowanie w działalność związkową może mieć jedynie charakter warunkowy. Cel zasadniczy: anarchia - konkludował włoski działacz - dalece wykracza poza horyzont myślenia liderów takich organizacji, jak CGT. Do tych kwestii zob.: P. H. Goodstein, op. cit., s. 72-74; D. Grinberg, op. cit., s. 127-131, 144-145; J. Joll, op. cit., s. 186-188; P. Laskowski, op. cit., s. 335, 345-355; F. Ryszka, W kregu zbiorowych złudzeń. Z dziejów hiszpańskiego anarchizmu 1868-1939, t. II, Warszawa 1991, s. 260-265.

40 Klasyczny przykład takiej argumentacji: V. Griffuelhes, op. cit., rozdz. III: Le patriotisme (http://www.pelloutier.net/dossiers/dossiers.php?id_dossier=112). Zob. też: F. F. Ridley, op. cit., s. 135-139. 
w rzeczywistości. W 1914 roku finałem kampanii antywojennej francuskich syndykalistów nie stał się bynajmniej strajk generalny, ani tym bardziej antyrządowe powstanie, lecz skierowane do robotników wezwanie, by przyłączyli się oni do obrony Francji przed Niemcami ${ }^{41}$.

Pogrążająca się w kryzysie CGT, u progu Wielkiej Wojny, w niczym oprócz retoryki nie przypominała już prężnej organizacji sprzed kilku zaledwie lat. Stan faktyczny nie wszędzie poza Francją był w pełni uświadamiany. Jak się wydaje, decydujący wpływ na podtrzymanie - wbrew oczywistym faktom - heroicznej legendy otaczającej syndicalisme revolutionaire miał Georges Sorel. Jego klasyczne już dzieło, opublikowane w 1908 roku Réflexions sur la violence, nie tylko zapewniło autorowi trwałe miejsce w dziejach myśli politycznej, ale na dobre stało się głównym punktem odniesienia wszystkich dyskusji i analiz dotyczących syndykalizmu. Sugestywny styl i niewątpliwy talent pisarski francuskiego myśliciela, ale także banalny na pozór fakt, że łatwiej jest przeczytać jedną książkę, aniżeli podjąć żmudną analizę teorii i praktyki działania CGT na przełomie XIX i XX wieku sprawił, że sorelowska interpretacja doktryny syndykalistycznej bywa także dziś - zwłaszcza w popularnych opracowaniach czy podręcznikowych ujęciach problemu - traktowana jako kanoniczna ${ }^{42}$.

Urodzony w 1847 roku Sorel był z wykształcenia inżynierem, a początki jego aktywności na polu ideologicznym przypadają dopiero na okres pół wieku późniejszy. W ostatnich latach XIX stulecia francuski myśliciel, poszukujący właściwego klucza do odczytania koncepcji Marksa, bliższy był raczej rewizjonistom pokroju Eduarda Bernsteina, aniżeli rewolucyjnym syndykalistom. Jeszcze w 1898 roku, pisząc rozprawę L'avenir socialiste des syndicats, przekonywał, że pożądanym wzorcem organizacyjnym dla ruchu robotniczego są angielskie trade-uniony, a zamiast idei strajku generalnego zalecał tworzenie spółdzielni. $\mathrm{Z}$ czasem punkt widzenia Sorela zaczął ulegać znamiennej ewolucji. W kolejnych tekstach autora coraz wyraźniej zaznaczała się krytyka demokracji i tego, co myśliciel określał jako „socjalizm polityczny”. Pod wpływem lektur, wniosków, jakie nasuwała analiza bieżącej sytuacji politycznej we Francji, a także rozmów z ciężko już chorym Pelloutierem, Sorel opowiedział się po stronie ruchu skupionego wokół CGT. Swoisty flirt ideowy ze środowiskiem syndykalistycznym nie trwał w przypadku autora Rozważań o przemocy długo, zaledwie kilka lat, okazał się jednak, jak już wspomniano, brzemienny w skutki ${ }^{43}$.

41 G. D. H. Cole, op. cit., s. 363-370; P. H. Goodstein, op. cit., s. 78-79; B. Tuchman, op. cit., s. 601; M. Waldenberg, Prekursorzy Nowej Lewicy..., s. 209-212, 231-232.

42 Por. trafne uwagi V. R. Lorwina, Syndicalism..., s. 448-449. Zob. też: F. F. Ridley, op. cit., s. 249; B. Russell, op. cit., s. 87.

43 Zob. przede wszystkim: I. Berlin, Georges Sorel, w: Essays in Honour of E. H. Carr, red. C. Abramsky, London 1974, s. 3-35. Pomimo upływu lat, godnym polecenia zarysem biografii intelektualnej Sorela pozostaje praca R. Humphreya, Georges Sorel. Prophet without Honour. A Study 
Publikując w 1908 roku dzieło życia, Sorel nie miał za sobą żadnych doświadczeń w pracy związkowej, także później nigdy nie był osobiście zaangażowany w działalność CGT. Jakkolwiek zaskakująco by to nie brzmiało, dorobek autora pozostawał praktycznie nieznany w środowiskach francuskich rewolucyjnych syndykalistów. Sytuacja nie uległa zmianie nawet po tym, jak na rynku czytelniczym znalazła się najbardziej znacząca z prac myśliciela. Liderzy CGT, Griffuelhes i Pouget odpowiadając na pytanie kronikarza ruchu zarzekali się, że nigdy w życiu nie zdarzyło im się czytać choćby fragmentu tekstu autorstwa Sorela ${ }^{44}$. Réflexions sur la violence, a także drugą szczególnie ważną książkę pisarza, Les illusions du progrès, trudno zatem potraktować inaczej aniżeli w kategoriach swoistych komentarzy wygłaszanych przez sympatyzującego z CGT, ale funkcjonującego poza tym środowiskiem, intelektualistę. Sam Sorel swoją rolę postrzegał jako służebną wobec ruchu robotniczego. Zgodnie z wyznawanym przekonaniem, że aspiracje les intellectuels do kierowania poczynaniami ruchu zawodowego należy uznać za szczególnie niebezpieczne, wyraźnie zaznaczał, że pozostając „na zewnątrz”, pragnie co najwyżej chronić proletariat przed inwazją wrogich idei ${ }^{45}$.

Punktem wyjścia analiz Sorela w drugiej połowie pierwszej dekady XX stulecia było przekonanie, że świat zachodni pogrążył się w kryzysie, z którego nie sposób wybrnąc inaczej niż proponując najbardziej radykalne środki. Cywilizacyjną zapaść Zachodu łączył pisarz z dominacją wartości mieszczańskich, na których zbudowana została liberalna demokracja. W ujęciu Sorela, znamionami przełomu XIX i XX wieku stały się bezideowość, cynizm, korupcja, kult pieniądza, słowem: pełna obłudy moralność kupiecka. Dostrzegając ostatnie jeszcze przejawy żywotności kapitalizmu w Stanach Zjednoczonych, autor skupił się na opisie „starczego uwiądu”, jaki rzekomo dotknął burżuazję zachodnioeuropejską,

in Anti-intellectualism, Cambridge Mass. 1951. Zob. także: J. Jennings, Introduction, w: G. Sorel, Reflections on Violence, Cambridge 1999, s. VII-XXI. Z literatury w języku polskim por. zwł.: J. Górnicka, „Cite Syndicaliste” Georgesa Sorela, „Colloquia Communia”, 1983, z. 1 (6), s. 29-58; L. Kołakowski, op. cit., s. 478-499; M. Król, Historia myśli politycznej. Od Machiavellego po czasy wspótczesne, Gdańsk 2003, s. 175-178; P. Laskowski, op. cit., s. s. 396-407; M. Waldenberg, Prekursorzy Nowej Lewicy..., s. 128-172; A. Wielomski, Syndykalistyczne korzenie francuskiego faszyzmu, „Studia nad Faszyzmem i Zbrodniami Hitlerowskimi”, 2003, t. XXVI, s. $5-12$.

44 Wspomniany Griffuelhes, pytany o Sorela, miał też z ironią odpowiedzieć, że czytał tylko książki Dumasa - P. H. Goodstein, op. cit., s. 74-75. Zdaniem F. Ridleya (op. cit., s. 249) trudno sobie wyobrazić, by szeregowi członkowie CGT znali prace w rodzaju Réflexions sur la violence. Brytyjski historyk wyraził jednocześnie pogląd, że nawet gdyby twórczość Sorela była przedmiotem zainteresowania środowisk robotniczych, to nie znalazłaby tam zrozumienia.

45 „Rozważania o gwałcie (Réflexions sur la violence) są filozofią moralności zbudowaną na zasadzie obserwacji zjawisk rewolucyjnego syndykalizmu [...]" - G. Sorel, Złudzenia postępu, tłum. E. Breiter, Kraków - Warszawa 1912 [I wyd. franc.: Paris 1908], s. 365. Zob. też: F. F. Ridley, op. cit., s. 249-252. 
zwłaszcza zaś francuską. Sedno sorelowskiej diagnozy stanowiła tu głęboka dezaprobata wobec postawy konsumpcyjnej i pragnienia pokoju społecznego. Sorel z pogardą pisał o skłonności do „zgniłych” kompromisów, akcentował zanik woli i energii, charakterystycznych cech znamionujących niegdyś „kapitanów przemysłu" ${ }^{4}$. Z taką samą pasją francuski myśliciel zaatakował racjonalizm europejskiej kultury, wskazując na niebezpieczeństwa wynikające z tworzenia symplicystycznych, wyspekulowanych modeli, redukujących całą złożoność rzeczywistości społecznej do uproszczonych, a więc fałszywych schematów ${ }^{47}$.

Ostrze sorelowskiej krytyki zostało też skierowane przeciwko tym środowiskom socjalistycznym, które lansowały pogląd, iż dzieło emancypacji proletariatu może się dokonać przy wykorzystaniu instytucji demokratycznych. W mniemaniu autora, reformizm socjaldemokracji zasługiwał jedynie na to, by napiętnować go jako oczywiste wypaczenie idei proletariackiej. Sorel nie miał wątpliwości, że „socjaliści parlamentarni” stanowią formację zaprzedaną burżuazji, akceptującą, na przekór wszelkim retorycznym zaklęciom, istniejący ład społeczny ${ }^{48}$. Pisarz konstatował równocześnie fakt, iż lewicowe partie zostały zdominowane przez „zawodowych polityków” o mieszczańskim i inteligenckim rodowodzie, a proces oligarchizacji tego rodzaju stronnictw w nieuchronny sposób prowadzi do alienacji partyjnych liderów od robotniczych „dołów”49.

Pisząc Réflexions sur la violence, Sorel miał już gotową odpowiedź na pytanie, co należy uczynić, by odwrócić niekorzystne tendencje. Sugestie myśliciela sprowadzały się do koncepcji „nowego początku”, rewolucji, która burząc zdegenerowany świat mieszczański, będzie obliczona na przywrócenie należnego miejsca w życiu społecznym temu, co wzniosłe, heroiczne, żywotne. W oczywisty sposób korzystając z przemyśleń takich autorów jak Pierre Proudhon i Henri Bergson, ale także Giambattista Vico, Friedrich Nietzsche i Ernest Renan, Sorel zapowiadał nadejście nowej cywilizacji: twórczej, wolnej od sentymentalizmu, przenikniętej rygoryzmem etycznym, tak bardzo kontrastującym z mentalnością burżuazyjną ${ }^{50}$. Celem zbliżającej się rewolucji nie miała być zatem - ta kwestia zasługuje na szczególne podkreślenie - zmiana polityczna, demokratyzacja

46 G. Sorel, Réflexions sur la violence, wyd. II, Paris 1910, s. 100-121; idem, Złudzenia postępu..., s. 298-299, 322-323.

47 Idem, Réflexions sur la violence..., s. 189-196, 200-201; idem, Ztudzenia postępu..., s. 41-63, 87-96, 144-145, 168-185. Zob. też: L. Kołakowski, op. cit., s. 484-488.

48 G. Sorel, Réflexions sur la violence..., s. 63-72, 143-150, 169-171, 179-181, 223-225, 233-234, 246; idem, Złudzenia postępu..., s. 132-134.

49 Idem, Réflexions sur la violence..., s. 225; idem, Złudzenia postępu..., s. 361-362.

50 „Im dłużej się nad tym zastanawiam, tym silniejsze zdobywam przekonanie, że praca może stać się podstawą nowej kultury, która bez żalu przejdzie ponad burżuazyjną cywilizacją. Wiemy o tym, że wojna, wydana przez proletariat swoim panom, powinna rozbudzić w nim uczucie wzniosłości, o którym współczesna burżuazja nie ma pojęcia" - idem, Złudzenia postępu..., s. 310. 
stosunków społecznych, ani tym bardziej ekonomiczny dobrobyt, ale rewitalizacja świata, rozumiana w kategoriach moralnych ${ }^{51}$. W zgodzie $\mathrm{z}$ wyznawanym przekonaniem o szkodliwości konstruowania skażonych grzechem racjonalizmu, obrazów przyszłości, Sorel unikał odpowiedzi na pytanie o losy ludzkości po upadku świata mieszczańskiego. Pisarz koncentrował swoją uwagę na samym akcie buntu przeciwko zastanej rzeczywistości, wierząc, że na gruzach starego ładu musi powstać jakościowo odmienny projekt cywilizacyjny ${ }^{52}$.

Właściwy Sorelowi sposób postrzegania realiów świata zachodniego na początku XX wieku wiązał się poszukiwaniem sił społecznych, która podejmą wyzwanie przywrócenia rodzajowi ludzkiemu zagubionych w erze burżuazyjnej wartości. Konkluzje zawarte $\mathrm{w}$ Réflexions sur la violence nie pozostawiają $\mathrm{w}$ tym względzie żadnych wątpliwości. „Klasę heroiczną” odnalazł autor w tych środowiskach proletariackich, które zanegowały punkt widzenia socjalistów pokroju Jeana Jaurèsa i bazując na strukturze czysto robotniczych syndykatów zdecydowane były na otwartą konfrontację z siłami starego porządku ${ }^{53}$. Wspomniany rys myśli sorelowskiej jest szczególnie istotny. Pisarz akcentował pogląd, że nową erę w dziejach ludzkości musi poprzedzić epoka dramatycznych zmagań i walk klasowych, a powodzenie przyszłej rewolucji zależy tak naprawdę od ukształtowania się postaw bohaterskich, co nie będzie mogło nastąpić na gruncie ,zgniłych kompromisów", a więc w efekcie faktycznej abdykacji obrońców dotychczasowego ładu ${ }^{54}$. Warto równocześnie podkreślić, że obraz zorganizowanych w ruchu związkowym mas robotniczych, jaki wyłania się na kartach Rozważań o przemocy miał $\mathrm{w}$ istocie niewiele wspólnego $\mathrm{z}$ realnie istniejącą CGT. Owładnięci mitem strajku generalnego syndykaliści z prac Sorela bardziej aniżeli francuskich proletariuszy początków XX stulecia przypominali - jak to ujął Leszek Kołakowski - „Homeryckich herojów widzianych oczyma Nietzschego”55. Trafna wydaje się również inna konstatacja poczyniona przez wybitnego polskiego filozofa i histo-

\footnotetext{
51 Idem, Réflexions sur la violence..., s. 186-188, 311-365; idem, Złudzenia postęu..., s. 283286, 366.

52 Kluczowa była w tym kontekście kategoria „mitu”, do której francuski autor się odwoływał. Por. zwł.: idem, Réflexions sur la violence..., s. 26-33, 38-43, 160-169, 185-186, 201-205. Charakteryzując sorelowski mit, L. Kołakowski (op. cit., s. 487) stwierdzał m.in.: „Mit nie jest żadnym opisem przyszłej rzeczywistości doskonałej; jest tylko perspektywą ostatecznej walki. Jego wartość nie jest poznawcza w przyjętym rozumieniu słowa, gdyż mit nie jest przewidywaniem naukowym; jest siłą, która organizuje walczącą świadomość zamkniętej grupy. Mitem proletariatu jest strajk generalny. [...] Jest stanem świadomości, która oczekuje i przygotowuje jednorazową, gwałtowną zagładę istniejącego świata, nie w ten sposób jednakże, by przeciwstawiała mu jakąś gotową konstrukcję przyszłego raju. W odróżnieniu od utopii mit ma nade wszystko funkcje negatywne". Zob. też: J. Joll, op. cit., s. 193-194.

53 G. Sorel, Réflexions sur la violence..., s. 155-160, 230-234; idem, Złudzenia postęu..., s. 147.

54 Idem, Réflexions sur la violence..., s. 105, 109-111, 179-181.

55 L. Kołakowski, op. cit., s. 495.
} 
ryka idei. Odnosząc się do wyraźnie obecnej w myśli Sorela apologii przemocy, Kołakowski zauważył, że francuskiemu myślicielowi chodziło o ,przemoc typu wojennego, nie zaś policyjnego, przemoc bez okrucieństwa i przemoc, której motywem nigdy nie jest zawiść ubogich do bogaczy - uczucie rujnujące moralnie i degenerujące proletariat" 56 . Sorelowski wzorzec ,przemocy moralnie godnej” nasuwał skojarzenia z aktami spontanicznej sprawiedliwości ludowej, kierował uwagę czytelnika ku czasom Iliady i Odysei, przywoływał wyidealizowane obrazy społeczności Wikingów czy wreszcie korsykańskiej vendetty ${ }^{57}$. Wspomniane fragmenty pism Sorela, w zestawieniu z charakterystycznym dla autora sposobem postrzegania instytucji rodziny, typowo konserwatywnym podejściem do zagadnienia tradycji, pochwałą ascezy i autentycznej, żarliwej wiary religijnej, to wszystko, skłaniało część badaczy do wniosku, że autor Les illusions du progrès w głębi duszy zawsze pozostawał tradycjonalistą, któremu bliskie były czasy gotyckich katedr, wypraw krzyżowych i heroicznych zmagań szwajcarskich górali o własne miejsce na ziemi ${ }^{58}$.

Wyrażoną w Réflexions sur la violence wiarę w ruch syndykalistyczny jako czynnik zdolny do stworzenia antytezy dla pogrążającej się w dekadencji cywilizacji mieszczańskiej Sorel porzucił po kilkunastu miesiącach. Trafnie oceniając, że CGT nie ma już w sobie rewolucyjnego potencjału, francuski myśliciel do ostatnich dni swego życia próbował odnaleźć zwiastuny nadchodzącej rozprawy ze światem demoliberalnym, którego tak bardzo nienawidził. Efekty owych poszukiwań, zarówno przed I wojną światową, jak i po roku 1918 przyniosły o tyle zaskakujące rezultaty, że Sorel w krótkim przecież okresie czasu zdążył związać swoje nadzieje kolejno z monarchistyczną, skrajnie prawicową Action Française, ruchem bolszewickim i wreszcie, włoskim faszyzmem. Wrażenie braku konsekwencji jest w tym wypadku raczej pozorne, myśl autora Rozważań o przemocy w swojej warstwie najbardziej podstawowej pozostawała niezmienna. „Sorel trafnie zauważył współczesny politolog Adam Wielomski, komentując punkt widzenia francuskiego myśliciela w tym czasie - zachwyca się tym, co irracjonalne i ideowe; popiera wszystkie ruchy ludzi wierzących w ideały, bez względu na to, czy będą to pierwsi chrześcijanie, komuniści Lenina, czarne koszule Mussoliniego, czy kameloci Maurrasa. Każdy mistyk, wizjoner i męczennik za swoje ideały, może liczyć na jego sympatię - gdyż każdy, kto w coś wierzy, jest żywą antytezą zmaterializowanego świata mieszczańskiego i jego produktów: liberalizmu, kapitalizmu, demokracji i dogmatyków marksizmu"59.

\footnotetext{
56 Ibidem, s. 491.

57 G. Sorel, Réflexions sur la violence..., s. 240-251, 253-309.

58 Taki sposób postrzegania zagadnienia znaleźć można m.in. u J. P. Blancharda - zob.: A. Wielomski, op. cit., s. 8-10.

59 Ibidem, s. 7.
} 
Praktycznie nieznany w środowiskach robotniczych Francji, a generalnie raczej lekceważony we własnym kraju, Sorel jeszcze przed I wojną światową zyskał rozgłos zagranicą, zwłaszcza we Włoszech ${ }^{60}$. Pisma francuskiego myśliciela wywarły niewątpliwy wpływ na kształtujący się na Półwyspie Apenińskim ruch syndykalistyczny, jakkolwiek od początku włoska wersja tej doktryny wykazywała pewne cechy odrębne ${ }^{61}$. Syndykalistyczni liderzy, tacy jak Arturo Labriola czy Enrico Leone nie podzielali charakterystycznej dla autora Réflexions sur la violence fascynacji filozofią Bergsona, ideę strajku generalnego postrzegali nie tyle w kategoriach sorelowskiego mitu, co raczej realnej walki robotników z fabrykantami, byli też zdania, że kontrolowana przez związki zawodowe partia polityczna może stanowić - choć w ograniczonym zakresie - jeden z użytecznych instrumentów $\mathrm{w}$ walce $\mathrm{z}$ kapitalizmem. $\mathrm{Z}$ czasem ten ostatni pogląd był artykułowany z coraz mniejszym przekonaniem, a działacze z Italii stopniowo zaostrzali swoje stanowisko wobec stronnictw politycznych. Wspomniany proces nie wydaje się specjalnie zaskakujący, zważywszy na fakt, że włoski syndykalizm stanowił secesję w łonie partii socjalistycznej. Labriola i jego zwolennicy podczas dwóch kolejnych zjazdów Włoskiej Partii Socjalistycznej (wł.: Partito Socialista Italiano, PSI), w Bolonii w roku 1904 i dwa lata później w Rzymie, bezskutecznie usiłowali podważyć reformistyczną orientację nadaną PSI przez kierownictwo stronnictwa z Filippo Turatim na czele. W połowie 1907 roku grupa syndykalistyczna opuściła szeregi partii, próbując odtąd przejąć wpływy w ruchu związkowym. Wysiłki zmierzające do nadania włoskiej Powszechnej Konfederacji Pracy (wł.: Confederazione Generale del Lavoro, CGL) pożądanego oblicza ideowego zakończyły się fiaskiem. CGL zachowała reformistyczny charakter, w konsekwencji środowisko skupione wokół Labrioli zdecydowało się u progu I wojny światowej powołać własną centralę związkową. Nieliczna Włoska Unia Związkowa (wł.: Unione Sindicale Italiana, USI) zaznaczyła swoją obecność przede wszystkim podczas fali strajków w czerwcu 1914 roku (tzw. „czerwony tydzień”), kierowanych jednakże głównie przez CGL ${ }^{62}$. Równocze-

${ }^{60}$ Sorel już pod koniec XIX wieku pisywał do włoskich gazet socjalistycznych, przez dłuższy czas utrzymywał też kontakty z prominentnymi przedstawicielami życia umysłowego Italii, m.in. z Benedetto Croce. Książki francuskiego myśliciela, tłumaczone na włoski, jeszcze przed I wojną były nad Tybrem szeroko komentowane bynajmniej nie tylko przez zwolenników idei syndykalistycznych - L. Kołakowski, op. cit., s. 483; M. Waldenberg, Prekursorzy Nowej Lewicy..., s. 244-246.

61 Warto zauważyć, że najważniejsze prace teoretyczne, które należałoby uznać za reprezentatywne dla włoskiego syndykalizmu ukazały się jeszcze przed publikacją sorelowskich Rozważań o przemocy. Chodzi tu przede wszystkim o drugie wydanie książki Arturo Labrioli Riforme e rivoluzione sociale i tekst autorstwa Enrico Leone zatytułowany Il sindicalismo. Obie wspomniane prace ukazały się w roku 1906.

62 P. H. Goodstein, op. cit., s. 95-102; V. R. Lorwin, Syndicalism..., s. 449; M. Waldenberg, Prekursorzy Nowej Lewicy..., s. 235-243, 246-288, 291-297; idem, Przyczynek do dziejów włoskiego socjalizmu, w: Studia z historii państwa, prawa i idei. Prace dedykowane profesorowi Janowi Malarczykowi, red. A. Korobowicz i H. Olszewski, Lublin 1997, s. 463-472. 
śnie w środowiskach włoskich syndykalistów nabrzmiewał konflikt, który osłabiał, i tak niewielką siłę oddziaływania USI. Jeszcze przed wybuchem I wojny światowej część prominentnych działaczy z Labriolą na czele zaczęła przechodzić na pozycje nacjonalistyczne. Pociągająca wizja konfliktu ,wielkiej proletariuszki Italii” z „obozem kapitalistów i plutokratów” sprawiała, że wielu spośród dawnych wrogów idei narodu i państwa zrewidowało dotychczasowy punkt widzenia. Wspomniany proces nie został bynajmniej zahamowany z chwilą przystąpienia Włoch do wojny w maju 1915 roku. Przekonanie, że „nacjonalizm proletariacki” stanowi siłę zdolną, w wyniku antyliberalnej rewolucji, nadać Italii nowe oblicze, z czasem miała przesądzić o akcesie znaczącej części środowiska syndykalistycznego do obozu Benito Mussoliniego ${ }^{63}$.

Przed wybuchem I wojny światowej idee syndykalistyczne zyskały pewną popularność także w kilku innych - poza Francją i Włochami - krajach europejskich. W latach 1911-1914 zupełnie marginalny dotąd ruch brytyjski, sprawnie kierowany przez Toma Manna, wyraźnie zaznaczył swoją obecność, angażując się w akcje strajkowe górników, kolejarzy i pracowników portowych ${ }^{64}$. W tym samym czasie znaczące środowiska syndykalistyczne pojawiły się także w Norwegii i Szwecji ${ }^{65}$. Z Niemiec, gdzie na lewicy zdecydowanie dominowała socjaldemokracja pochodził Robert Michels, autor klasycznego dzieła Zur Soziologie des Parteiwesens in der modernen Demokratie. Pozostając niewątpliwie pod wpływem Sorela, ten wybitny socjolog polityki dowodził, że nowoczesne partie polityczne w sposób nieuchronny podlegają procesowi oligarchizacji.

63 R. Paxton, Anatomia faszyzmu, tłum. P. Bandel, Poznań 2005, s. 60; M. Waldenberg, Prekursorzy Nowej Lewicy..., s. 289-290; A. Wielomski, op. cit., s. 10-12, 20. Warto zaznaczyć, że również na gruncie francuskim można odnaleźć u progu I wojny ślady analogicznej tendencji. Chodzi tu przede wszystkim o swoisty flirt ideowy, jaki z Action Française, za zgodą i aprobatą Sorela podjęła grupa jego uczniów. Utworzone pod patronatem autora Rozważań o przemocy i Charlesa Maurrasa, Koło Proudhona (franc.: Cercle Proudhon) na krótko stało się forum współpracy radykalnych środowisk młodzieżowych wrogich liberalnej demokracji. Sojusz rozpadł się w obliczu spodziewanego konfliktu Francji z Niemcami, większość młodych syndykalistów - za przykładem samego Sorela - uznała że przeciwko Rzeszy, stanęły do walki zachodnie plutokracje, a więc taka wojna nie może zyskać aprobaty. Szerzej na temat środowiska Cercle Proudhon, w którym część badaczy dostrzega zapowiedź kiełkującego ruchu o charakterze narodowo-socjalistycznym zob.: J. Bartyzel, „Umierać, ale powoli!”. O monarchistycznej i katolickiej kontrrewolucji w krajach romańskich 1815-2000, wyd. II, Kraków 2006, s. 631-632, 696-697; R. Paxton, op. cit., s. 59-60; A. Wielomski, op. cit., s. 10, 16-20; idem, Nacjonalizm francuski 1886-1940. Geneza, przemiany i istota filozofii politycznej, Warszawa 2007, s. 187-195.

64 Obszerna analiza problemu w cytowanej wyżej książce R. J. Holtona British Syndicalism..., s. 27-201. Por. też: H. Pelling, A History of British Trade Unionism, Harmondsworth 1963, s. 135-141; W. H. Fraser, A History of British Trade Unionism 1700-1998, wyd. III, Basingstoke 1999, s. 123-126; A. Zandberg, „Ociężali umysłowo, głupi oportuniści”. Wczesna brytyjska lewica radykalna wobec ruchu zwiazkowego, „Dzieje Najnowsze”, 2006, nr 1, s. 3-17.

65 W. Galenson, Labor in Norway, Cambridge Mass. 1949, s. 20-24, 59-61; V. R. Lorwin, Syndicalism..., s. 450. 
Wspomniana tendencja w sposób szczególny dotyczyć miała socjaldemokracji, która zamiast reprezentować robotników przekształciła się w biurokratyczny aparat, służący realizacji grupowych interesów intelektualistów mieszczańskiego pochodzenia i stała się de facto jeszcze jedną instytucją podtrzymującą kapitalistyczny porządek ${ }^{66}$.

W Hiszpanii zwolennicy budowania potęgi ruchu robotniczego w oparciu o związki zawodowe wywodzili się z posiadającego na Półwyspie Iberyjskim długą i bogatą tradycję ruchu anarchistycznego. Centrum hiszpańskiego rewolucyjnego syndykalizmu stanowiła w pierwszych latach XX wieku najbardziej uprzemysłowiona prowincja kraju, Katalonia. W 1907 roku, w Barcelonie powstała regionalna federacja związków zawodowych pod nazwą Solidarność Robotnicza (hiszp.: Solidaridad Obrera). Inicjatorzy przedsięwzięcia zamierzali z czasem rozszerzyć obszar oddziaływania organizacji. Rozwój wydarzeń sprawił, że impulsem do powołania ogólnokrajowej centrali związkowej, odwołującej się do idei syndykalistycznych stała się pacyfikacja dokonana przez wojska rządowe w czasie tzw. „tragicznego tygodnia”, pod koniec lipca 1909 roku, gdy akcja strajkowa barcelońskich robotników przekształciła się w krwawe walki uliczne. Decyzję o utworzeniu struktury ponadregionalnej podjęto na zjeździe zorganizowanym przez Solidaridad Obrera w stolicy Katalonii, na przełomie października i listopada 1910 roku. I Kongres Krajowej Konfederacji Pracy (hiszp.: Confederación Nacional del Trabajo, CNT) odbył się we wrześniu 1911 roku, również w Barcelonie. Zdominowana od początku przez anarchistów CNT zaczynała z niskiego pułapu, liczba jej członków w pierwszych miesiącach istnienia organizacji nie przekraczała zapewne 30 tysięcy ${ }^{67}$. Z czasem cenetistas stać się mieli prawdziwą potęgą, najsilniejszym bez wątpienia ogniwem międzynarodowego ruchu anarchosyndykalistycznego. Jak zwrócił uwagę Grinberg, nawet w okresie największej świetności, gdy liczba członków CNT przekraczała milion, formuła organizacyjna Konfederacji pozostawała zbliżona do wzorca zakreślonego w 1895 roku przez Pelloutiera ${ }^{68}$.

Na początku XX wieku idee syndykalistyczne znalazły zwolenników także na drugiej półkuli. Spośród krajów Ameryki Łacińskiej, w tym kontekście należy wymienić przede wszystkim Argentynę, w dalszej kolejności także Chile, Mek-

66 R. Michels, Political Parties. A Sociological Study of the Oligarchical Tendencies of Modern Democracy, transl. P. Cedar, P. Eden, New York - London 1968 [I wyd. niem.: Zur Soziologie des Parteiwesens in der modernen Demokratie, Leipzig 1911].

67 Zob. przede wszystkim: M. Bookchin, op. cit., s. 143-160; S. Payne, The Spanish Revolution, New York 1970, s. 16-35. Por. też: P. H. Goodstein, op. cit., s. 86-92; P. Laskowski, op. cit., s. 366-369; F. Ryszka, op. cit., t. II, s. 268-269.

68 D. Grinberg, op. cit., s. 143. Jedynym stałym funkcjonariuszem CNT opłacanym ze składek członkowskich był wybierany raz na 5 lat, sekretarz generalny - zob.: M. Bookchin, op. cit., s. $160-161$. 
syk i Urugwaj ${ }^{69}$. W Stanach Zjednoczonych samo pojęcie syndykalizm nie było popularne, sympatyków koncepcji przebudowy społecznej w oparciu o związki zawodowe bynajmniej jednak nie brakowało. Amerykańskim odpowiednikiem CGT w jej najbardziej bojowym okresie, stała się po roku 1908 organizacja Robotnicy Przemysłowi Świata (ang.: Industrial Workers of the World, IWW) ${ }^{70}$. IWW została powołana do życia trzy lata wcześniej przez środowiska rozczarowane strategią i efektami działań Amerykańskiej Federacji Pracy (ang.: American Federation of Labour, AFL). Nowa centrala związkowa była początkowo terenem ścierania się różnych radykalnie lewicowych tendencji, wyraziste oblicze ideowe przybrała na kongresie we wrześniu 1908 roku, gdy rywalizacja o przywództwo zakończyła się zwycięstwem Williama Haywooda ${ }^{71}$. W przyjętej deklaracji, określającej cele strategiczne ruchu autorzy odwoływali się do kategorii walki klas, wskazując, że będzie ona trwać do czasu aż zorganizowani w związkach zawodowych robotnicy przejmą kontrolę nad środkami produkcji. Charakterystycznym rysem przywołanego tekstu było wyrażone przez liderów IWW przekonanie, iż formuła organizacyjna społeczeństwa przyszłości kształtuje się już w ramach starego porządku wraz z urzeczywistnianiem hasła „One big union”72.

Okres dynamicznego rozwoju Industrial Workers of the World trwał niespełna dekadę ${ }^{73}$. Po przystąpieniu USA do I wojny światowej, ,,Wobblies”, podobnie jak inne środowiska uznane za wywrotowe, zostali poddani represjom. Haywood, skazany na wieloletnie więzienie zdołał opuścić Amerykę, co charaktery-

69 V. R. Lorwin, Syndicalism..., s. 450; S. F. Simon, Anarchism and Anarcho-Syndicalism in South America, „The Hispanic American Historical Review”, 1946, nr 1, s. 38-59 [tekst dotyczy także okresu po 1914 roku].

70 Wskazując na oczywiste podobieństwa, należy rzecz jasna mieć też na uwadze specyfikę Industrial Workers of the World. IWW rekrutowała swoich zwolenników przede wszystkim wśród robotników niewykwalifikowanych, imigrantów, często bezdomnych i analfabetów. Jak trafnie stwierdził V. R. Lorwin (Syndicalism..., s. 450): „The Wobblies, as IWW memebers were called, were activists to the core, rough in language, and little interested in theory. Proposing the revolutionary expropriation of the properted classes and the abolition of the wage system, they advanced a crude theory of the social organization of the future by industrial unions". Na temat podobieństw i różnic między IWW a CGT por. też: J. Billington, op. cit., s. 437-438; R. Tyler, The Rise and Fall of an American Radicalism: The I.W.W., „Historian”, 1956, vol. XIX, s. 57-59. Patrz także: M. Dubofsky, Socialism and Syndicalism, w: Failure of a Dream? Essays in the History of American Socialism, wyd. II, red. J. H. Laslett, S. M. Lipset, Berkeley 1984, s. 170-203.

71 J. Bekken, Industrial Workers of the World (IWW), w: Historial Encyclopedia of American Labor, t. I, red. R. E. Weir, J. P. Hanlan, Westport - London 2004, s. 244-245; P. F. Brissenden, Industrial Workers of the World, w: Encyclopaedia of the Social Sciences, t. VIII, New York 1958, s. 13-15; B. Tuchman, op. cit., s. 572-573.

72 Tekst słynnej Preamble to the IWW Constitution został przywołany w artykule J. L. Kornbluha, Industrial Workers of the Word, w: Encyclopedia of the American Left, wyd. II, red M. J. Buhle et al., New York 1998, s. 356-357.

73 Według J. Bekkena, licząca jeszcze w 1911 roku nie więcej niż 13 tys. członków organizacja, 6 lat później osiągnęła już 100 tysięcy - op. cit, s. 245-246. 
styczne wyjechał do Rosji, gdzie władzę przejęli bolszewicy. Jakkolwiek IWW przetrwała trudny okres, nigdy już nie odzyskała dawnej siły oddziaływania, tracąc przy tym znaczną część zwolenników na rzecz ruchu komunistycznego ${ }^{74}$.

Kryzys syndykalizmu nie był jedynie zjawiskiem lokalnym, typowym dla Stanów Zjednoczonych. Analogiczne procesy miały miejsce w innych krajach, nie wyłączając Francji i Włoch. W okresie międzywojennym, syndykaliści byli wprawdzie obecni w życiu politycznym Europy i obu Ameryk, ale ich wpływ na rzeczywistość społeczną - poza szczególnym przypadkiem Hiszpanii - był raczej znikomy. Wzbierająca fala nastrojów antydemokratycznych i antyliberalnych największe korzyści przyniosła tym ruchom politycznym, ku którym u schyłku życia zwrócił swe nadzieje Sorel: komunizmowi i faszyzmowi.

\section{Syndicalism - movement and doctrine before Word War I}

The term syndicalism appeared at the end of the nineteenth century and was assimilated by the revolutionary fraction of the union movement in France. With time it also became popular in other countries, especially in Italy and Spain. The characteristic features of the syndicalistic doctrine in the discussed period are as follows: 1) anticapitalistic attitude combined with the belief that the unions will play the basic role not only in the rebuilding of the political system but also in the society of the future; 2) the thesis that the future of the world depends on the results of the class struggle conveyed on economic grounds; 3) activism, voluntarism, glorification of spontaneous activities; 4) rejection of the party model in political activities, criticism of the liberal-democratic system.

Contrary to the widely spread - also nowadays - opinions, syndicalism has never been a homogeneous movement. Side by side with the dominating revolutionary stream, aiming at the liquidation of the state, with time the movement gave rise to a reformist current.

The "golden years" of syndicalism ended with the outbreak of World War I. The causes of such a state of affairs are complex and they should not be explained by the simple statement that the movement was losing its impact for the benefit of the growing influence of communism and fascism.

74 Ibidem, s. 246-247; P. F. Brissenden, op. cit., s. 15-16. 